\title{
"What the fuck is this for a language, this cannot be Deutsch?" language ideologies, policies, and semiotic practices of a kitchen crew in a hotel restaurant
}

\author{
Kellie Gonçalves ${ }^{1}$
}

Received: 15 April 2019 / Accepted: 8 August 2020 / Published online: 29 August 2020

(c) Springer Nature B.V. 2020

\begin{abstract}
In line with the post-Fishmanian turn that contributes to new understandings of social-semiotic practices in different contexts this study is concerned with the language management of 'backstage performers' of a three-star hotel kitchen crew in an Austrian alpine village that economically thrives on tourism, where employers and employees do not always share a common 'language'. Recent free mobility labor rights for certain EU citizens have facilitated economic migrants' ability to work abroad while simultaneously filling labor shortages within the country's service industry in peripheral zones that are salient economic hubs. Drawing on ethnography and moment analysis, results indicate that for language-marginal occupations such as dishwashers, linguistic entrepreneurship is resisted since relying on shared semiotic repertoires and material objects for communicative purposes is preferred given the physically demanding occupation and stressful moments in a restaurant kitchen. The study questions Spolsky's recently modified theory of language policy and management concerning the individual level regarding 'advocates without power' and employability contributing theoretical insights to on-going explorations of bottom-up LPP.
\end{abstract}

Keywords Language management · Hotel family business · Semiotic repertoires · Peripheral alpine region $\cdot$ Austria $\cdot$ Language ideologies $\cdot$ Social practice $\cdot$ Moment analysis

Kellie Gonçalves

kellie.goncalves@uni-koeln.de

1 Englisches Seminar I, Universität Zu Köln, Albertus-Magnus-Platz, 50923 Cologne, Germany 


\section{Introduction}

In his modified and enriched theory of language policy and management, Spolsky (2018) recently discussed amendments made to his original theory that consists of three interrelated parts, namely, language practices, language beliefs or ideologies and language management. Indeed, all of these components are closely and complexly intertwined and can rarely be discussed on their own without consideration of the other components. In amending the management component, Spolsky calls for an addition to be made. Not only are those in positions of power to be scrutinized, but so too are their apparently powerless counterparts, i.e. what he terms "advocates (without power)" (2018). Secondly, he raises the issue of the individual level, resonating with the earlier work of Jernudd and Neustupný (1987) and Neustupný and Nekvapil (2003), which must also be considered "noting the importance of self-management, attempts to expand personal repertoires to enhance communication and employability" (ibid.). Indeed much sociolinguistic research set in multilingual workplaces, especially in the tertiary sector, have been concerned with the heightened importance of communication skills and the so-called "entrepreneurial self" (Burchell et al. 1991) as characteristics of the current neoliberal era (Cf. Urciuoli 2008; Lorente 2012, 2018; Duchêne and Heller 2012; Allan 2013; Duchêne et al. 2013) and what De Costa et al. (2016, 2018) have recently referred to as linguistic entrepreneurship within the context of education. On the individual level, this means understanding subjects as active, neoliberal agents, calculating individuals in constant pursuit of self-improvement, enhanced opportunities, profitability and overall better life chances (Gershon 2011, 2017; Dardot and Laval 2014). Linguistically, much of this work presupposes that effective communication is grounded in speakers' proficiency in either the host country's target language or a lingua franca. In these ways, language appears to be conceptualized from a monolithic perspective according to positivist modernist sociolinguistics that continues to be critiqued (García et al. 2017) and recently referred to as "outdated" Spotti et al. (2019).

In line with the recent "paradigm shift in sociolinguistics" and the post-Fishmanian turn (Bell 2014; Blommaert 2016), language here is conceptualized as a "social practice with speakers drawing on all kinds of linguistic resources for their own purposes" (Bell 2014: 9) as well as other semiotic resources and practices. In this paper, I am concerned with 'the language management' of a threestar hotel kitchen in an Austrian village, where employers and employees may not always share similar linguistic repertoires and question how we might account for 'language management' in language-marginal occupations (McAll 2003), i.e. jobs that require minimal language contact and language use to get work done such as dishwashers. What happens, for example, when the promotion of linguistic entrepreneurship by means of language learning is not taken up, rejected (Holborow 2015) and resisted by workers themselves in such language-marginal positions? In other words, what happens when workers do not necessarily internalize neoliberal values? There seems to be an underlying assumption by many scholars that (economic) migrants or individuals in 'low-skilled' jobs (and otherwise) are 
constantly searching for ways of self-improvement and socio-economic mobility (although see chapters in Martín Rojo and Del Percio 2020), but what occurs when this kind of circulating discourse, hegemonic ideology and neoliberal narrative does not actually have significance for the individuals in question? For employees who are located at the lower end of the socio-economic scale concerned primarily with economic survival rather than self-development through the accumulation of skills, one of which is language, how are employees managed linguistically and/or semiotically when their jobs do not require much language at all? As scholars of language policy and taking to heart Spolsky's latest amendments, how do we account for individuals who do not necessarily invest (Norton 2000; Darvin and Norton 2015, 2016) in language learning as a skill of the host country in order for self-improvement to occur, and symbolic and cultural capital to be accrued? In a recent paper, Pennycook (2017) stated that, "as long as language policies deal with languages as countable and fixed entities, there will be a disjuncture between language policies and practices". The focus of Pennycook's work was questioning whether the state is the single key player in language policy and whether language ideologies that favor statist orientations to language are used. For the context of this study, Austrian standard German is the majority language and operational at the scale of the nation-state only, but not necessarily within a workplace that often relies on multilingual, multimodal and thus semiotic repertoires, where actual use of language is often marginal. This entails taking a bottom-up approach and investigating language policies and practices on the local and micro-level of the workplace where language ideologies, language practices, and individual and collective semiotic repertoires may possibly be deemed as nonstandard or deviant to outsiders, but within this particular community of practice, the absolute norm in terms of how individuals' carry out their daily workplace interactions. This means, "taking a close ethnographic inspection of the minutiae of what happens in communication" (Blommaert 2016: 247). As such, the empirical goal of this paper is to present findings on the semiotic practices in a multilingual kitchen while theoretically contributing insights to ongoing explorations of bottom-up LPP, linguistic entrepreneurship and a repertoire approach.

\section{Semiotic repertoires and rural spaces}

In their recent work on semiotic repertoires, Kusters et al. (2017) discuss the relevance of incorporating multimodal and multilingual aspects of communication along with a more nuanced understanding of translanguaging that recognizes the different ways in which individuals draw on their multimodal linguistic resources in order to make meaning (2017: 220). They call for an incorporation of the visual-gestural modality of communication that includes signs, gestures, body orientation and the use of objects, which they refer to as individuals' 'semiotic repertoires' erasing the strict distinction between linguistic and non-linguistic ones (2017: 221) echoing earlier work done by Rymes (2014) on communicative repertoires that questioned monolithic perspectives of language. This all-encompassing multimodal approach 
goes far beyond looking at language or linguistic resources and repertoires only, but aims to capture a more complex and perhaps complete picture of how communication is achieved among interlocutors in different multilingual contexts. The relevance of body comportment within gesture studies and studies of multimodality is not new nor is the fact that we communicate by utilizing semiotic means beyond language novel from an integrationist perspective (Harris 1998). Nevertheless, such views of communicative repertoires and semiotic ones in particular seem to have gained momentum in recent years within both applied linguistics and sociolinguistics with regard to the 'translingual turn' especially within educational contexts (Rymes 2014; Canagarajah 2013; Pennycook 2017; Sherris and Adami 2019) questioning positivist assumptions about language as stable, countable entities. The impetus of Pennycook and Otsuji's (2015) work on metrolingualism was to look at linguistic and semiotic repertoires outside educational domains and focus on the different resources people deploy in interaction across workplace contexts in city centers. Scholars such as Blackledge and Creese (2017) and Adami (2019) have continued to investigate embodied, multimodal and semiotic practices within urban settings and markets in particular since these places are considered to be 'superdiverse' (Vertovec 2007) lush with dynamic complexity and difference including of course language (Arnaut et al. 2016). ${ }^{1}$ Indeed, much work within sociolinguistics focusing on multilingual language practices and areas of contact have tended to favor urban centers (Blommaert et al. 2005; Otsuji and Pennycook 2010; Pennycook and Otsuji 2015; King and Carson 2016; Hua et al. 2017) presumably because cities have the reputation of being more cosmopolitan and thus more multicultural and perhaps even more multilingual than their rural counterparts (although see Pietikäinen et al. 2016; chapters in Sherris and Adami 2019, for counter-discussions). Within the field of variationist studies, Britain (2012) has referred to such scholarly tendencies as encompassing an "urban fetish". There is no doubt that language contact occurs in large metropolises, but such contact is also prevalent in suburbs, towns and even small rural villages. As such, spaces and places considered to be peripheries have and continue to transform or develop into salient economic hubs under globalization processes (Pietikäinen et al. 2016: 2; Banda et al. 2019; Pietikäinen and Allan in press; Strömmer in press), one of which is tourism, a fertile site of transnational contact and labor.

\section{Global and local tourism: the case of Walsen, ${ }^{2}$ an Austrian village}

Tourism, as a major form of (elite) global mobility (Thurlow and Jaworski 2010; Gonçalves 2020), is recognized as the world's largest service industry (Adey, 2010, p. 2), which, until the COVID-19 pandemic, employed around 240 million people annually (World Travel and Tourism Council; Adey, ibid.). The saliency of the tourism industry in Austria accounted for 5.6\% of its GDP in 2015. On a regional scale, it is also an important economic factor in that approximately $89 \%$ of the work

\footnotetext{
1 For a critique of superdiversity see the work of Pavlenko (2019).

2 Walsen is a pseudonym as are all personal names in this article.
} 
directly related to tourism is provided by regional workers, i.e. food services, carpenters (Kolleritsch 2004; WKO 2017: 8; Dannerer and Franz 2018: 170). For Dannerer and Franz, "tourism creates and sustains employment" with "nearly every fifth job in Austria [being] related to tourism or the leisure industry" (ibid.). On a local scale, the village I call Walsen located within the province of the Salzburger Land (where the hotel is situated), ranked \# 27th in Austria, economically thrives on tourism with over 290,000 registered overnight stays (Statistics Austria 2017). For a village of roughly 1000 inhabitants, the international demand of tourism clearly outweighs the supply of local workers.

In fact, the service sector in this small rural village is the largest employer for local, regional and international employees. According to the Austrian Labour Migration Report (Biffl 2016: 112) "migrants make up 21\% of all employees in housekeeping and restaurant services. The major groups are third country nationals ( $12 \%$ of all workers), followed by other EU-15 nationals (5\% of all workers in 2009 , largely from Germany), by citizens of EU-10 countries (3\%) and EU-2 countries (1\%)". ${ }^{3}$ Most of the foreign workers from the new EU Member States are citizens from the Czech Republic, Slovakia, Poland and Hungary, i.e., nationalities that made up a sizable proportion of the foreign workforce in Austria prior to EU-enlargement (Biffl 2016: 101). The number of Romanians has also increased significantly since EU membership in 2007 (2016: 112); in 2014, quotas for seasonal work were further reduced as Bulgarians and Romanians received free mobility of labor rights allowing them to work without having to go through the bureaucratic process of applying for seasonal work permits (Biffl 2016: 27). Simu, this study's main participant, is a Romanian, whose decision to move to Walsen year-round and work as a dishwasher at the Ferienhof hotel was facilitated by free mobility labor rights within the EU regardless of his language competence in any German variety.

While Standard Austrian German is operational at the level of the nation-state, the regional Pongau dialect and/or local Walsen dialect are the varieties mainly used among locals in Walsen when they communicate with one another. These dialects share several features with Southern Bavarian dialects and thus considered to be mutually intelligible (Russ 1990; Wiesinger 1990). The linguistic features of these dialects differ on all linguistic levels to Standard varieties (both Austrian and German) paralleling a case of diglossia (Ferguson 1959) making it less or even non-intelligible and therefore more challenging for learners of Standard German varieties.

\footnotetext{
3 EU-15 designates the number of member countries prior to the accession of ten candidate countries in 2004. These consisted of Austria, Belgium, Denmark, Finland, France, Germany, Greece, Ireland, Italy, Luxembourg, Netherlands, Portugal, Spain, Sweden, and the UK. In 2004, the following ten countries became EU members Cyprus, the Czech Republic, Estonia, Hungary, Latvia, Lithuania, Malta, Poland, Slovakia and Slovenia. EU-2 countries consist of Romania and Bulgaria that joined in 2007.
} 


\section{Data collection and methods}

I gained access to the Ferienhof through personal ties. A close family member of mine is part of this business that was established in the 1970s. It is a three-star hotel equipped with a restaurant located at the end of a valley in a small village within the Salzburger Land, located approximately $40 \mathrm{~km}$ from Salzburg. It has roughly 1000 inhabitants and economically thrives on tourism. The majority of guests that come to the Ferienhof hail largely from Germany, the Czech Republic, Holland and England. ${ }^{4}$ In the winter season, guests primarily come for tour skiing, downhill and cross-country skiing and snowboarding, and in summer, the clientele consists largely of Eastern European tour groups and paragliding schools from Germany and Switzerland. The summer guests come to Walsen and to the Ferienhof in particular primarily to hike, mountain bike and paraglide.

I moved to Walsen and more specifically to the Ferienhof in late December 2013 and lived there semi-permanently until February 2017, afterwards commuting biweekly from Oslo, Norway. As a close family member and resident of the Ferienhof, I have been allowed unfettered access into every space of the hotel and know all of the 14 staff members personally, some better than others due to the length of their employment and working hours. The hotel is not only a workplace for some and a holiday destination for others, but it is also my family's home. In fact, we live in a small apartment in the hotel located on the third floor. While residing in a workplace that is not my own has both advantages and disadvantages, the rather close encounter with seasonal guests and staff have allowed me to observe first-hand how a family-operated business functions in terms of its management that caters to a global clientele and its international staff. I received permission to carry out this study and conduct interviews with staff members in the summer of 2017. For the purposes of this paper, I draw on participant observation, field notes, and two interviews in particular, one from the head chef, Alex, who is a local Austrian, and the other from Simu, a dishwasher and kitchen assistant from Romania. Interviews were conducted in the hotel during low-peak times and lasted between 20 and $60 \mathrm{~min}$. In addition to these interviews, I spent well over 200 hours in the kitchen in 2017 where I observed participants and took extensive field notes on how communication was achieved between the wait staff and kitchen crew as well as within the kitchen crew only.

Because the staff knew me relatively well on a personal level, my presence inside the kitchen did not seem to affect their communicative interactions despite my role as a female researcher and a close family member of Ferienhof's management. Many times, when I was present in the kitchen, the kitchen crew went about their daily business and tasks with music playing loudly in the background and therefore not taking much notice of me at all. My presence became marked and somewhat uncomfortable to some of the kitchen crew, and one chef in particular when rather inappropriate jokes were being made. This seems to resonate well with the incongruity theory of humor said to provide relief to tensions and stress of the workplace

\footnotetext{
${ }^{4}$ According to Statistics Austria (2017), guests from Germany, Holland, the Czech Republic, the UK, UAE, Denmark, Belgium, Poland, Sweden and the USA make up the top ten countries visiting Austria.
} 
(Morreall 1991). According to Lynch (2009: 445) this theory "argues something can be found to be funny if it is irrational, paradoxical illogical, incoherent, fallacious and/or inappropriate". Indeed, workplace humor and in-group cohesiveness go hand in hand (Holmes and Marra 2002) and because I was not part of this particular in-group or "interactional regime" (Blommaert et al. 2005), I had to learn their inside jokes, their in-group 'semiotic repertoires' and ways in which this kitchen crew made sense of their work on a daily basis. In essence, I had to be socialized into this linguistic and cultural environment (Roberts 2010) in order to better understand what people actually do with the linguistic and semiotic repertoires they have at their disposal.

The need to investigate the semiotic repertoires and practices enacted in the Ferienhof's kitchen, and to better understand how language policy and practice is exercised from below meant that I had to employ a mixed methodological approach that draws on both moment analysis (Wei 2011) and "thick description" (Geertz 1973) of ethnography in search of particularity (Hornberger 2015: 17). Moment analysis focuses on the creativity and criticality of multilingual spaces requiring a paradigm shift away from pattern recognition approaches to a "focus on spontaneous, impromptu, and momentary actions and performances of the individual" (2011: 1224). For Li Wei, "a moment can be a point or a period of time which has outstanding significance. It is characterized by its distinctiveness and impact on subsequent events or developments" (ibid.). In fact, a moment can become "a reference point" (ibid.). While moment analysis requires different types of data sources that include observations, recordings of naturally occurring talk and meta commentary, I was not able to audio record interactions for two main reasons. First, one chef, Levin, did not consent to being recorded. Second, recordings within this kitchen would have ultimately proven problematic as there was often loud music playing in the background and loud kitchen appliances including mixers and grills making recordings of any kind difficult to transcribe. As such, I focused on my observations, field notes and interviews with participants.

\section{The kitchen as a "hidden domain"}

A hotel restaurant kitchen is largely considered to be what I call a "hidden domain", an area that is mainly restricted to its workers and usually off limits to outsiders, customers and hotel guests. This is primarily due to hygienic food-handling purposes despite the increased popularity and trend of open kitchen restaurants, which gained recognition and prominence in the 1990s (Baraban and Durocher 2010). The notion of a 'hidden domain' encompasses what Goffman might call a 'back stage' performance, where individuals, in this case, chefs and other kitchen crew members' activities and performances are not on display for public viewing or carried out before a "particular set of observers" (Goffman 1959: 32). Research conducted on the communicative practices among individuals within kitchen contexts is rare. This may be due to the methodological challenges of gaining access to such sites, but partly due to this industrial setting as a "noisy" workplace resonating with the 
findings of McAll (2003) and Holmes (2011) statement about blue-collar workplaces. ${ }^{5}$ A handful of studies exists examining the communicative practices within restaurant settings (Barrett 2006; Pennycook and Otsuji 2015; Schluter 2014, 2018; Pang 2018; Sohn and Lee 2018) but none have focused solely on semiotic practices within the confines of the kitchen crew only. This study deviates from previous studies in kitchen contexts in that it investigates the different kinds of semiotic repertoires and practices in interaction shedding light on broader social, spatial and semiotic dynamics at play within a complex translanguaging space. It does this by investigating semiotic repertoires in situ along with the metadata on the ways in which communication and meaning-making is achieved provided by the research participants themselves.

It will be shown that for certain occupations, especially those considered to be language marginal, the ideology of linguistic entrepreneurship through language investment is not necessarily taken up but often resisted. In fact, language proficiency in the majority language is not a prerequisite for employment or socio-economic mobility within the company hierarchy. This has to do with the high demand and rather low supply of finding suitable manual workers willing to fill these particular labor shortages regardless of individuals' language competences at the national, regional or local level. As LPP agents themselves, these workers are in a position to manage their own linguistic and semiotic repertoires, where top-level management in turn is expected to adapt to workers' repertoires and creative ways of communicating rather than the other way around.

\section{Semiotic practices in a multilingual kitchen}

The kitchen is considered to be a multilingual (and multimodal) workspace that relies heavily on material and semiotic resources, individuals' diverse repertoires and collective social practices that are often, but not always, devoid of actual spoken language during peak meal times. This means that the deployment of gestures and use of artifacts well known to the kitchen crew often override the use of actual spoken language by means of orders and requests. When language is used, depending on who is speaking, variation results with the uses and mixtures of the regional Austrian Pongau dialect, an East German Saxon (sächsisch)-Swabian (swäbisch)/ Pongau dialect mix, very little English and some Standard Austrian German. While Standard Austrian German is considered to be the majority language and operational at the scale of the nation-state level, within the Ferienhof's kitchen, this is by far not the case.

When it comes to actual spoken language, those at the top of the workplace hierarchy (Figure 1), whose status and position of power is "clear and uncontested" (Holmes and Stubbe 2015) tend to employ more spoken language such as directives (Pang 2018) than those at the bottom. Within this particular workspace, Alex, the

\footnotetext{
5 In 2011 Holmes stated that noise, dirt and discomfort were likely reasons why so few studies in language and blue-collar workplace had been done acknowledging the need for more studies in this area.
} 
Figure 1 The Ferienhof's restaurant workplace hierarchy displaying the kitchen crew, and information on their national backgrounds and linguistic repertoires in 2017. Note: All names are pseudonyms in order to protect individuals' anonymity

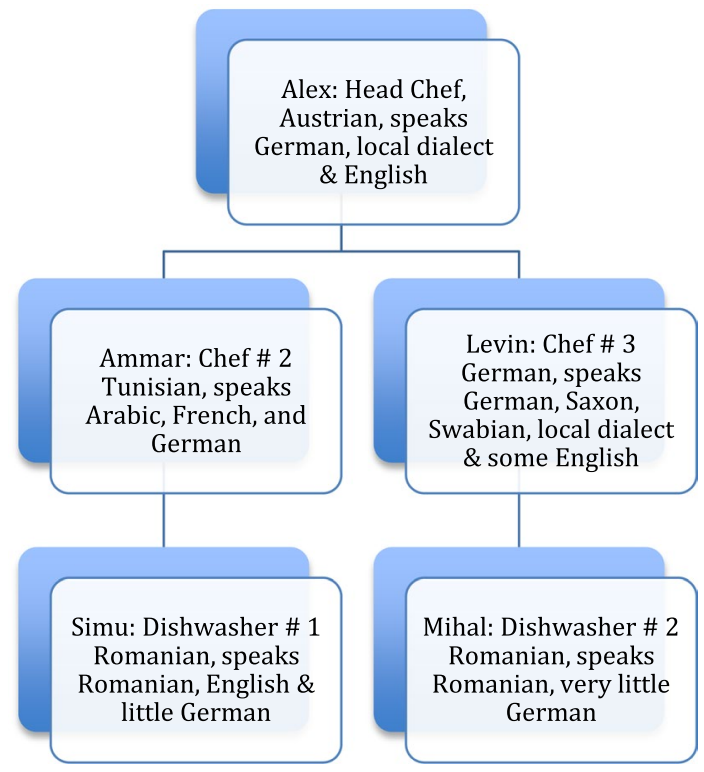

executive chef, is the only Austrian employed and co-owner of the family business. $\mathrm{He}$ is in charge of the kitchen's overarching ability to function smoothly especially during peak meal times. He, together with the two sous-chefs, Levin and Ammar, meet on a regular basis to discuss both weekly and daily menus, the ordering of kitchen and food items as well as food preparation. Alex is also in charge of delegating tasks to Simu, who despite his position as the main dishwasher, also experienced some social mobility and became a kitchen assistant over the course of his five-year employment as a result of his diligence and willingness to learn about cooking and meal preparation in order to assist both sous-chefs at stressful times.

The stress level in any kitchen regardless of size can significantly skyrocket when multiple orders come in consecutively. This has been attested to by Bourdain's published accounts in Kitchen Confidential (2007), by the kitchen crew at Ferienhof, as well as my own observations in this workspace. As such, all members of the kitchen need to work jointly as a team by engaging in multiple tasks in order to prepare, cook and deliver food to guests in a timely manner that must all be 'orchestrated' (Hua et al. 2017). The pressure to perform and deliver under acute time constraints often means that there is no time for lengthy discussions or explanations. In fact, during the busiest hours in winter, which is lunchtime from 12-14:30, the kitchen crew can cater to up to 1200 individuals, meaning that linguistic communication is often left out of the equation entirely. ${ }^{6}$ According to both Alex and Simu, the higher

\footnotetext{
${ }^{6}$ Serving over 1000 meals within less than two hours does not happen on a daily basis at the Ferienhof, but the workload and stress placed on the kitchen crew to perform is extremely high. In comparison to Pang's study, a restaurant kitchen that served the same number of meals (1000) a day had 12 chefs working in the kitchen simultaneously.
} 
Table 1 Ferienhof's food codes

\begin{tabular}{lll}
\hline Kitchen code & Food item in German & English translation \\
\hline Wie & Wiener Schnitzel & Breaded pork \\
Kl. Wie & Kleine Wiener Schnitzel & Small breaded pork \\
Kl. Wie os & Kleine Wiener Schnitzel ohne Salat & Small breaded pork without salad \\
P. OK & Pommes ohne Ketchup & Fries without ketchup \\
P. RW & Pommes rot weiss & Fries with ketchup and mayonnaise \\
\hline
\end{tabular}

the stress level, the less spoken language is used, which is also supported by my own observations.

Like many modern restaurants, the Ferienhof's system of placing orders is done electronically and through mediated means during dinner shifts. When a waiter or waitress takes a table's order, it is typed into the till electronically by a 'front stage' waiter/waitress, which produces an automated receipt along with the table number that is printed out in the kitchen. This receipt is then taken by Levin, the sous-chef, and called out in what he self identifies as a "misch-masch Sprache", a mix of elements and features of Saxon, Swabian, Pongau dialects and Standard German. At this point, every member of the crew is aware of their duties and executes their specific tasks. ${ }^{7}$ During lunchtime when there is also a hot buffet in the restaurant, waiters or waitresses who take additional orders, which have to be prepared directly in the kitchen, write down orders on a piece of paper in "kitchen code", enter the kitchen, confirm the order verbally in the regional Pongau or local Walsen dialect and sticks the receipt on a specific open counter for all employees to consult if necessary. Table 1 depicts some of the dishes and their respective codes that are handwritten by wait staff.

At that point, the kitchen crew, all of whom are individually responsible for their specified tasks, which collectively allow for punctual meals to be served, engage in their own jobs. Individual tasks are discussed among Alex and employees during recruitment and hiring and may change over the course of employment depending on employees' performance.

As the executive chef and co-owner of the Ferienhof, Alex is indeed in the highest position of power, however, his management style is non-authoritative and very collegial. This has to do with his own personal style, similarities in age among him and his staff as well as his concern and priority for keeping his staff satisfied with their working conditions. As much as his staff rely on their jobs for economic reasons, Alex equally relies on his staff in order for the overall kitchen, where a large portion of business earnings stem, to function well. As such, he makes a concentrated effort to please his staff by allowing them to make agentive decisions not only

\footnotetext{
7 According to Alex and also my own observations, if it is a large and complicated order, both Alex and Ammar also consult the electronic receipt.
} 
about food-related matters and customer concerns, but also about how communicative and semiotic practices are managed and deployed among the kitchen crew.

As previously indicated, $21 \%$ of workers within the Austrian service industry are comprised of foreign migrants. Indeed, the high demand for work in such industries cannot be met with the rather low supply of local, regional and national workers. This, together with EU regulations of free mobility of labor rights has led to an influx of foreign workers taking on low-skilled jobs (Biffl 2016) such as dishwashers and kitchen assistants. Most of the Ferienhof's employees are comprised of migrant workers from Eastern Europe whose L1 is not German. In discussing the recruitment process with me, Alex spoke about different sub-groups of employees who deal directly or indirectly with clients. This categorization resonates with what Goffman (1959) might call 'front stage performers' (i.e. owners, receptionists and wait staff). All front-stage performers within the business have direct contact with clients and hotel suppliers on a regular basis as opposed to more 'back stage performers' like the kitchen crew, whose work is absolutely essential for a business like the Ferienhof to function, but rarely ever seen by guests or clients echoing with Duchêne's (2011) account of workers' 'invisibility'.

\section{Participants}

\section{Alex: executive chef and co-owner of the Ferienhof}

At the time of our interview, Alex was 32 years old. He had trained as a chef in a regional culinary school about $40 \mathrm{~km}$ from Walsen and completed an apprenticeship. Alex also worked abroad in England for five years during the European summer months, considered to be the 'low season' for his family business, where in addition to gaining international experience, he also learned English. During the winter months and thus high season of his family's business, he always returned back to Walsen to work in the Ferienhof alongside his grandmother, who established the business nearly 40 years ago. During those years, his grandmother was the head chef at the Ferienhof and taught Alex how the kitchen functioned, could be managed and also passed along specific recipes that are still used today. Subsequent to her retirement nearly a decade ago, Alex became the executive chef taking on all responsibilities year round. In addition to his kitchen duties, he also assists his family in running the hotel and is jointly responsible for making decisions regarding recruitment of all hotel and kitchen employees. Our interview was conducted in English since that was Alex's preference.

\section{Simu: Romanian migrant, dishwasher and kitchen assistant}

At the time of our interview, Simu was 34 years old. He was born and raised in Romania, where he had been university educated and worked as a civil engineer for several years. With very long hours and a stressful job situation, he and his girlfriend, Anja, decided to move to Austria as labor migrants and for reasons of family 
reunification (on the part of Anja). Simu spoke Romanian, English and a little German at the time of our interview. He had learned English at school and university and some German vocabulary and fixed phrases from his previous employment. Before coming to the Ferienhof, Simu had already worked in another small Austrian village as a dishwasher. The couple moved to the Ferienhof together to work during the winter season, Simu as a dishwasher and Anja as a cleaner. Together they also lived in the hotel, which allowed them to save on accommodation and food costs. Our interview was conducted in English since that was Simu's preference.

\section{Managing employees}

\section{Recruitment practices}

When asked about the challenges of finding kitchen crew members, Alex stated: Extract (1)

1. because it a, erm...the reputation, basically there's a huge lack of, of, of people that can

2. and want to work in this business, in this industry, you know? erm, specially in catering

3. [gastronomy] you're working on weekends, you work nights erm, then you know for

4. example when I take my generation most people didn't do an apprenticeship to become a

5. mechanic or electrician or chef, or waiter and, maybe thirty, forty years ago this was

6. different because this was seen to be a proper job, but these days erm you know everyone

7. wants to go to academia, they want to make a living and money not through physical

8. work, because I think it is seen as a, a, lower caste thing to do

In extract (1), Alex differentiates between white-collar and blue-collar jobs highlighting the socio-economic class differences and opposing socio-cultural connotations attached to both types of occupations. His claims are based on the Austrian system of schooling and the changing demographics of the national labor force (lines 5-8), which contrary to Alex's assumptions, are not accurate. According to a recent OECD report (2014), "Austria has one of the lowest graduation rates for upper secondary and post-secondary non-tertiary programs designed to prepare students under 25 for tertiary-type A education (38.9\%, ranking 25 of 27)". In fact, vocational education and training continues to be a salient pillar within the Austrian education system with " $76 \%$ of students who were enrolled in upper secondary education participated in pre-vocational or vocational programs" making it the second highest percentage among OECD countries (OECD 2014). For Alex, jobs requiring vocational training are characterized by manual labor, long hours, and are negatively evaluated socially, culturally, and economically (lines 3, 7 and 8), which is made manifest by his comment that partaking in such jobs is perceived as "a lower caste thing to do". With changing educational trends within contemporary society, these apprenticeships, especially within the culinary context according to Alex are becoming difficult to fill, which is also related to the seasonal nature of the job making outsourcing of flexible economic migrant laborers the key to solving many recruitment challenges. One of the observations I made at the Ferienhof was the management's 
ability to retain their staff with relatively low employee turnover rates resonating with what Goodall and Eisenberg (1997) describe as the "old social contract", while other neighboring businesses in the village were experiencing high turnover rates.

Employees are one of the key components in the operation of any successful business (Davidson 2003; Karatepe and Olugbade 2009; Gonçalves and Schluter 2017, forthcoming), and according to Li et al. (2013) are possibly the "main drivers of competitive advantages in the hotel industry" where the creation of an effective service climate is crucial and enhances employees' services and loyalty to the organization (Costen and Salazar 2011) especially in "the age of organizational anxiety" (Barker and Tompkins 1994: 223). When I asked Alex about the management's strategy to maintain a loyal staff, he stated.

Extract (2)

1. Alex: well erm you know we don't look down at them because they are foreigners you

2. know? I think we respect them as, as, as you know? as human beings and we don't give a

3. shit about nationality, which in many, in many businesses, in [gastronomy] is not the case

4. you know? because for some reason some, you know Austrians, feel superior and they

5. make jokes about the Turkish or the Yugoslavian or you know, the foreigners but when

6. you think that about our business, the only Austrians who work here, they are actually all

7. family, all the other people are from other countries

8. Kellie: so you guys are the minority?

9. Alex: we are by far the minority yeah, we have, you know at the moment we have two

10. Germans, we have two waitresses that are local they erm you know come and help out

11. so they are like of other professions, but they come and help out in some situations but

12. erm, we could not sustain a business without the foreigners so obviously it must be how

13. they are paid otherwise they wouldn't come back, so we don't differentiate between

14. nationality, and I think they know, it's a family kind of business and they all belong

15. somehow to the family.

In extract (2) Alex describes the individuals in his family business as adhering to the same ideology, i.e. the set of values, ideals and understanding about employees regardless of their national origin and foreign status. In his assertion, he makes use of the plural pronouns "we" and "them", both of which are discursive forms used to index inclusion and exclusion and serve to create what Anderson (1991) calls an "imagined community". For Alex, migrant workers are vital for sustaining a family business such as his (line 12), and a point he finds many local businesses within Walsen (most of which are family-run) do not necessarily respect (lines 3-5). This becomes clear when he draws on the national label Austrian (line 4) and juxtaposes himself and his family members with "we". Furthermore, his explanation about Austrians feeling superior about their national status and making jokes about Turks and Yugoslavs is a point that may resonate with the political and media discourse with regard to the Austrian right-wing populist Freedom Party (FPÖ), which has for almost a decade campaigned against immigration with political slogans primarily targeting Turkish minorities and Muslim immigrants (Wodak and Boukala 2015). Despite it being an international holiday destination and workplace for many, the local village of Walsen as a peripheral area is regarded as a traditionally conservative 
place that in many ways is also politically oriented towards the right. And while late modernity may indeed 'detraditionalize' particular spaces according to Giddens (1991), conservative political ideologies appear to be more of a rule rather than an exception within Walsen that may be both categorized and stigmatized by its antiimmigrant and anti-minority politics.

While Alex asserts that their employees' loyalty is due to the way they are treated as "human beings" (line 2), their salary (line 13), and being part of the "family" (lines 14-15), my observations of the kitchen crew also revealed a kind of "organizational osmosis" described by Gibson and Papa (2000) as "the seemingly effortless adoption of the ideas, values and culture of an organization on the basis of preexisting socialization experiences" (2000: 79). ${ }^{8}$ Indeed I was able to observe a strong masculine solidarity and camaraderie among the kitchen crew, whose semiotic repertoires and often playful practices were socially meaningful and displayed their close relationships, group identity, and overall commitment to the team.

\section{Managing repertoires}

In discussing how communication works in the kitchen, Alex states the following: Extract (3)

1. Alex: the main language is German so obviously it's different if we have someone in the

2. kitchen helping washing the dishes he doesn't have to have a full understanding of the

3. language because, we have, can get ways around it sometimes we even, we use google, as

4. a tool but then erm, in the kitchen we have, we talk German there's one German chef, and

5. In the winter there are two Romanian dishwashers [...] it's not possible to talk to one of

6. the Romanian dishwashers because his German is really poor so we have a, middle-man

7. [Simu] which is, the first dishwasher so, we talk to him either in German or English and

8. he needs to convey information to his helper [Mihal], this is how we communicate and

9. then there's another chef that is from Tunisia, his mother tongue is French, but he

10. speaks German fluently and English so in certain situations especially with the main

11. dishwasher (Simu) who's actually a help in the kitchen, [...] he is fluent in English and I'd

12. say, in certain situations more, you know more accurate erm, [...] like his understanding 13. of English is sometimes greater so sometimes when I communicate with him, and 14. there's like a misunderstanding or he doesn't get it erm we switch to English

As Alex explains in extract (3), English is used as the de fault lingua franca with Simu, although multilingual, multidialectal and multimodal practices are used

\footnotetext{
8 All potential employees are invited to the Ferienhof for a personal interview prior to hiring. At these meetings, the management meet with potential employees, but also socialize with them, i.e. have drinks and snacks together in order to get to know them on a personal level. If potential employees have traveled far, they are often invited to stay at the hotel in order to get a better idea of how it operates. The management spend the evening with the potential employees chatting and drinking in order for both parties to get to know one another on an informal basis. In these ways, the interview may be seen as a form of investment and preview of how potential employees will be treated reflecting the values of a familyoperated business.
} 
among the kitchen crew depending on the context and interlocutor. In addition to his dishwashing and kitchen assistant duties, Simu also functions as the main language broker (Tse 1996) engaging in "inter-employee brokering" (Gonçalves and Schluter 2017) with Mihal. Despite his linguistic competence and ability to mediate between Alex, the two sous-chefs and Mihal, he is not afforded extra monetary benefits for his extra linguistic work, a finding similar to Duchêne (2011) and Hess (in press). For Alex, a dishwasher does not require a full command of German (lines 2-3) and ways around it can be managed either through the use of online translation services or what I often observed through a combination of 'truncated repertoires' (Blommaert 2010), gestures, body language, semiotic repertoires and thus "semiotic assemblages" (Pennycook and Otsuji 2015) "where meanings emerge from momentary assemblages of material and semiotic resources intersecting at a given place and time" (Hua et al. 2017: 388). In these ways, Alex and the other sous-chefs have no choice but to accommodate to Simu's repertoires rather than Simu accommodating to their repertoires given the complex, multilingual, multidialectal and multimodal situation present within the kitchen space.

A typical and perhaps even representative example of the communicative and semiotic practices within the kitchen crew during high-peak dinner time in winter is when the automated receipt is printed out in the kitchen, called out by Levin in "misch-masch Sprache" (multidialectal variety with several features of Standard German) prompting individuals to adhere to their delegated tasks. During lunchtime when electronic receipts are not used, the waiter/waitress enters the kitchen and calls out the entire order in the local Walsen dialect or regional Pongau dialect and leaves the written order (in code) on the counter. If any misunderstandings occur, this is quickly resolved between Levin and the waiter/waitress. The actual space where all three chefs work is relatively small and confined usually allowing Alex and Ammar to hear conversations between Levin and the waiter/waitress. For reasons of clarity or when loud music is playing, Levin calls out the corrected order verbally a final time and, when a task is required of Simu directly, he usually incorporates gestures to signify what needs to be done. For example, if Levin calls out to prepare "fünf Suppen, drei Pommes, einmal OK, zweimal RW und zwei Schnitzel" (five soups, three fries, one without ketchup, two with ketchup and mayonnaise and two breaded pork), which are three tasks that contribute to one table's order to be handled by himself (fries), Simu (soups) and Alex (pork). To confirm the soups with Simu, Levin would call out "fünf Suppen" by directing his gaze at Simu and simultaneously hold up his hand showing all five of his fingers followed by pointing to the soup bowls. Together, the language, eye gaze and gestures used by Levin at that precise moment denote an order specifically aimed at Simu to leave the dishwashing station immediately and complete a sous-chef's request fairly quickly in order that the meals be prepared concurrently.

\section{Creative practices in the kitchen}

Of all of the interactions I observed, one moment in particular became marked due to the changes it triggered in the previous patterns of the kitchen crew's 
communication with regard to salad preparation. This event occurred when the family's Brazilian-Portuguese-speaking au pair, who did not speak English or German at the time, came into the kitchen one afternoon to get some food. As usual, she walked in, smiled and waited for someone in the kitchen to acknowledge her. Her mere presence in this space indexed to the others that she wanted something to eat. Depending on who was in the kitchen at the time, Simu, Levin or Alex usually catered to her needs by walking around the kitchen, employing deictic gestures (Norris 2004) by pointing to the different types of food they had either readily available such as soups, specific sauces, and pastries or food that they could quickly prepare like salad (pointing to the salad bar), omelets (pointing to or holding up eggs), pasta (holding up a bag of pasta), meat (by opening up a refrigerated drawer that had various types of cut meat in it) or fries (by holding up the iconic 'fry bowl' or pointing to the deep fryer). At times, the au pair would also point in a specific direction, indexing a particular food, e.g. the refrigerated drawer meant "meat". Most times, the au pair also wanted salad in which she uttered "salada, pepino e tomate" (meaning salad, cucumber and tomato) in her regional Brazilian-Portuguese variety equipped with the post-alveolar, voiceless affricate [t $]$ in the word tomate while simultaneously pointing to these items in the salad bar. In these ways, meaning emerged from the semiotic assemblages of the individual repertoires, the kitchen space, and material objects there. Alex describes this moment as follows:

Extract (4)

1. Alex: the one before from Brazil, that didn't talk, didn't speak English, so you know that

2. was a bit of a erm you know body language you know, and sounds, obviously she came up

3. with words like alface pepino e tomate and then it became like an ongoing joke you know

4. like, [...] "oh alface pepino tomate" so, this is quite interesting when you have four or five

5. people that talk maybe six or seven languages but sometimes you don't have a bridge

6. between individuals and then you go through a middle man that grabs a few words that

7. you understand and make a joke of all of it.

8. Kellie: mhm so, when you talk about this joke, the "alface pepino tomate" I mean I think

9. you guys don't you still use this because I've heard you in the kitchen?

10. Alex: yeah we still use this, you know for example Levin, in German he asked soll ich erm

11. [tomates schneiden] in English like "should I cut some tomates" you know? or "do we

12. have pepino?" so erm in a way, it sounds like a creation of, like our own isolated room of

13. communication where different languages are being combined, everyone gets it,

14. everyone gets it who is involved and was a part of the historic, development of meaning

15. in a way.

16. Kellie: $\mathrm{mhm}$

17. Alex: so, maybe from an outside point of view it sounds crazy because it doesn't make 18. any sense but we get it.

Moment analysis focuses on creativity with a particular "focus on spontaneous, impromptu, and momentary actions and performances of the individual" (Wei 2011: 1224). Indeed, the Brazilian au pair's utterance and marked pronunciation of "alface, pepino" but especially tomate that was simultaneously paired by her gestures of pointing to these items became a moment that was characterized by its 
significance so much so that it became "an ongoing joke" (line 3) and impacted the way in which the kitchen crew discussed and still discusses salad preparation. The kitchen crew's linguistic repertoires contain a total of five or six 'languages', some of which get drawn on or lexical items "grabbed" (line 6) in order for meaning to be achieved. For those unfamiliar with the languages used in the kitchen, "body language" (line 2) and from my observations, an array of semiotic and material objects are also employed and function to either support verbal communication or standalone semiotic resources that index a specific meaning. From the above extract, the kitchen emerges as a hidden domain and "isolated room" which suggests that contact with others is rare, but nevertheless is in fact an important translanguaging space (Wei 2011) where semiotic repertoires and assemblages are created and devised among members in their communicative endeavors and daily work interactions. Indeed, only those who contributed to this co-creation and co-construction of knowledge and meaning making from its inception and development (lines 13-15) may actually understand their respective interlocutors and their ensuing semiotic performances resonating with Wei's (2011: 1223) assertion that space is also created through translanguaging.

\section{Language ideologies and non-investment}

From my observations and experiences with Simu, his level of German was proficient despite his aversion towards it, which he describes in extract (5).

Extract (5)

1. Simu: I came here it was actually in a small erm village and they were all talking like, with accent so

2. an accent so a dialect like I couldn't understand nothing, I said "what the fuck is this?" what is this

3. for a language this cannot be Deutsch? can't be Deutsch so I can say my erm German doesn't really

4. didn't really change in the last two years that's because I had no interest to learn it, I find it a

5. difficult language, a complicated language and it has no.... it has no, I don't know to define, it

6. doesn't sound right for me, it sounds crazy, really, @@@ (laughs)

According to Gal (2006: 13), language ideologies can be viewed as "cultural ideas, presumptions and presuppositions with which different social groups name, frame and evaluate linguistic practices". Indeed, Simu evaluates the named language "Deutsch" (German) while making a negative ethno-metapragmatic statement based on cultural ideologies (Silverstein 1992) of regional and local Austrian dialects. This is due to the phonological, morphological and lexical differences found in these dialects that deviate considerably from both Standard Austrian German and Standard German (Clyne 1984; Russ 1990; Smith and Baker 2011). The differences found on all linguistic levels coupled with Simu's rudimentary Standard German made the local dialect unintelligible and instantaneously disvalued, leading to his interrogative and expression of disbelief in "what the fuck is this for a language, this cannot be Deutsch?" (line 3). For Simu, the reality and everyday use of a local dialect in his former workplace rather than that of Standard Austrian German led to his disinterest and ultimately, his dis or non-investment in either variety. In follow up conversations 
with Simu, the time, energy and contexts required to learn, use and speak the local dialect or Standard Austrian German in the two years, where he worked year-round at the Ferienhof (both the winter and summer season) were not afforded to him on a regular basis, nor did he specifically seek them out, although he admitted to watching shows like South Park in Standard German for their amusing content, relying on online translation services and Alex for assistance with specific lexical items. Nevertheless, his disinclination for both the local Walsen and regional Pongau dialects and, eventually, even standard Austrian German stem primarily from their grammatical structures and prosodic features including tone, tempo and rhythm (lines 5 and 6). In these ways, Simu does not internalize neoliberal values associated with skills accumulation concerning language learning for reasons of workplace advancement and possible self-improvement. Instead, he presents himself as, quite frankly, a non-aspiring German user who resists acquiring just about any German variety and therefore also the ideology of linguistic entrepreneurship. At the same time, however, he presents himself as an agentive LPP agent, who is aware of his value on the team as a manual laborer, where verbal communication (and proficiency) for his job is not a priority. As such, Simu is able to communicate by any means he can prompting others to follow his lead and accommodate to him.

\section{An emic account of communication}

In discussing communicative interaction in the workplace, Simu admits to counting on "all my language that I know" while at the same time relying on "body language" to make himself understood, which he describes in extract (6) below:

Extract (6)

1. Kellie: how would you describe the language situation in this workplace, because there are lots of

2. different people that work here that have different languages, right?

3. Simu: it works, it works I don't know how but erm it works, I can erm I can make me understood

4. with erm with all my language that I know and I think erm, we... we, understand each other, not

5. only with the language but also with the body language

In this extract, Simu admits that while he cannot exactly pinpoint the linguistic situation in the workplace, presumably because it is so complex and becomes a combination of semiotic assemblages where different material, semiotic, linguistic and embodied practices and repertoires are deployed for meaning-making to occur between the kitchen crew, communication is achieved and meaning making "works" (line 3). The repetition and more specifically, the parallelism found in the grammatical structure "it works" functions to emphasize Simu's claim (cf. Johnstone 2002) that despite the rather idiosyncratic ways in which communication is achieved, it functions well for this particular community of practice that have over time established ways and patterns of communication that have become mutually intelligible within this particular space. In these ways, Simu, "an advocate without power" (according to Spolsky 2018) actually emerges as a powerful 
LPP agent, whose semiotic ways of communicating have set the tone for his coworkers, who end up accommodating to him despite his language-minority status. Interestingly here, we also get a glimpse regarding the 'languaging' (Pennycook and Otsuji 2016) (line 4) and thus Simu's emic perspective of what he does, which is to employ "all my language" suggesting that he is well aware of the different linguistic and semiotic repertoires (including body language) needed for him to be understood as well as to understand and communicate with others.

As previously mentioned, stressful times in the kitchen create moments that are bereft of language use altogether. In my interview with Simu, he describes such moments as "automatic" and thus robotic, alluding once again to the interrelated roles of space, social, embodied and semiotic practices and objects that are used and move among kitchen crew members thus underscoring the dynamic relations and relationships among them as a team and their specific work practices, which over time become systematic, habitual and eventually mundane, which also matches my own observations:

\section{Extract (7)}

1. Kellie: how is it for example because I know that there is sometimes when it's quite stressful [...]

2. especially in winter at lunchtime it can be really erm crazy I've seen that

3. Simu: @ @ @ (laughter)

4. Kellie: how do you cope with this? With these situations, with the language and the stress, it's a few

5. things all at once so how do you erm manage this?

6. Simu: erm I think that we are a working team and most of the time when we have so much to do

7. that it's a lot of stress in the kitchen we work like robots, it comes always natural you don't erm the

8. little things you hear [waiters] calling erm everyone knows what he has to do it's like automatic,

9. it's automatic, so we don't, we have no time to speak and say "Alex, please can you make erm two

10. pommes [two portion of fries]?" And you hear "two pommes" and you know, this is Levin's job or

11. this is mine or when both of them are busy, I try to help them and do whatever I can

The teamwork required in this particular space resonates with what Hua et al. (2017) refer to as "orchestration", "where different instruments contribute to the making of music and no one instrument is more or less significant than another, [and where] multiple lingual and modal semiotic resources work together in meaning-making" (Hua et al 2017: 388). For these scholars, orchestration also requires "attunement", (Pennycook and Otsuji 2015) the ways in which people, in this case, chefs, dishwashers and kitchen assistants receive their "cues" and become in sync with each other, different objects in the kitchen, like plates and food items (such as fries) in order to perform their culinary duties and deliver dishes in a timely manner. In moments of restricted time constraint, attunement is key since the kitchen crew has "no time to speak," indexing the relevance to read both the situation and individuals and respond accordingly. 


\section{Conclusion}

In line with the post-Fishmanian turn that contributes to new and different understandings of social-semiotic practices, I have investigated a hotel restaurant kitchen crew and their workspace in order to understand how communication is managed by means of a case study. My results revealed that contrary to many sociolinguistic studies set within multilingual workplaces that emphasize the saliency of language proficiency, language skills and linguistic entrepreneurship, acquiring the host country's majority language or the local dialect was not necessary for employability, social mobility within the company hierarchy or even a prerequisite for successful communication among co-workers within a highly multimodal space. Spolsky's recent amendment to his tri-part model of language policy makes manifest that apart from looking at nation-states and institutions in order to better understand how language is managed, we also need to consider the individual level and the linguistic entrepreneurship that is invested in concerning individuals' self-improvement and motives that are largely dominated by socio-economics. Investigating the individual level is by all means relevant to any model of language policy especially within workplace contexts, however, to what extent should we categorize individuals as "advocates" "with" or without power", the latter usually pertaining to employees while the former is reserved for employers and managers. To adhere to an either/or categorization and assume that those "without power" are active neoliberal agents relentlessly searching for self-improvement, better life chances and thus constantly investing in themselves through acquiring skills, one of which may be language by means of linguistic entrepreneurship may not be the most useful way to think about how individuals are managed or how they manage themselves linguistically and or semiotically. This is especially the case with individuals and employees located at the lower-end of the socio-economic scale, whose work is often manual, physically strenuous, low-level and largely considered to be language-marginal. Uncritically accepting the hegemonic neoliberal narrative that has and continues to prevail in studies set within multilingual workplaces especially within the tertiary sector that continue to frame 'language' according to positivist modernist sociolinguistics fails to sufficiently address recent theoretical debates taking place in both applied linguistics and sociolinguistics with regards to conceptualizations about 'language' and a repertoire approach.

Within the field of language policy, more work is needed in language and workplace studies especially within blue-collar contexts that question the ideological notions of language, language commodification, linguistic entrepreneurship and neoliberal agendas (see Pennycook in press), the latter of which is not always uncritically adhered to, but at times, even resisted. This is especially the case for jobs that require minimal spoken language, where using generic language labels does not accurately account for what is happening among interlocutors. Within the context of this study, jobs such as dishwashers are in high demand and have predominantly been occupied by economic migrants as a result of free mobility labor rights within the EU. This pertained to Simu and his decision to move to Walsen, 
which was an example of downward mobility given his educational level. Of course, language matters, but as McElhinny (2015) pointed out, it might not always be the most relevant issue at hand. Within the context of the Ferienhof's kitchen crew, linguistic skills or a 'common language' was certainly not the most salient issue among employers and employees especially in a sector where labor shortage prevails. For Alex, as one of the co-owners of the family business, executive chef and manager of the kitchen crew, hiring diligent and reliable employees, who are able to take on demanding, physical workloads, work long hours, work on weekends, learn quickly and are team-oriented, appeared to be the main criteria regardless of prospective employees' backgrounds, language proficiencies or linguistic repertoires.

Due to the labor shortages present within the local and even national context and therefore also the lack of competition among prospective employees, Alex's choices with regard to recruitment are quite slim. As a result, Alex as well as his sous-chefs must often (as was the case with Simu) quickly adapt their language management and ways of communicating towards lower-level employees rather than the other way around. In these ways, power asymmetries among employers and employees are not always clear-cut or top-down, but at times, bottom-up. Indeed, Simu's linguistic skills as a dishwasher were not the main criteria for his advancement to kitchen assistant. Within the context of this kitchen, social mobility occurred in a space that was dependent on a lot more than a common or "good" "language" or even similar linguistic repertoires, but a range of semiotic repertoires and assemblages that consisted of semiotic, spatial and material resources within a given translanguaging space. As such, the kitchen as a "hidden domain" revealed the sociolinguistic realities of the participants in their daily workplace interactions, which rely on individuals' creative uses of their total semiotic repertoires in order for meaning-making to occur and communication to be achieved, a point Simu pointed out when referring to "all my language". When emic and etic perspectives converge, perhaps it is time to question and reassess the labels (Gumperz 1965; Rymes 2014) and ideological inventions' (Makoni and Pennycook 2006) employed by individuals, scholars and particular sub-fields in order to advance our epistemological stances. As long as scholars continue to talk about 'language' as a countable entity, a view that is not only 'outdated' but strips individuals of their creative resources and potential to draw on a wide-range of semiotic and material resources, repertoires and objects within certain socio-cultural and historical political contexts, the 'disjunctures' between policies and practices will inevitably continue.

Acknowledgements This work was supported by the Research Council of Norway through its Centres of Excellence funding scheme, Project number 223265. I would like to thank the kitchen crew at Ferienhof, especially to Alex and Simu for their willingness to take part in this study. I would also like to extend my thanks to Kristin Vold Lexander, Olga Solovova, Johan Järlehed, Robert Blackwood and two anonymous reviewers for their helpful comments on earlier drafts of this paper. All shortcomings are my own. 


\section{References}

Adami, E. (2019). Multimodal sign-making in today's diversity: The case of Leeds Kirkgate Market. In A. Sherris \& E. Adami (Eds.), Making signs, translanguaging ethnographies: Exploring urban, rural and educational spaces (pp. 36-54). Bristol: Multilingual Matters.

Adey, P. (2010). Mobility. New York: Routledge.

Allan, K. (2013). Skilling the self: The communicability of immigrants as flexible labour. In A. Duchêne, M. Moyer, \& C. Roberts (Eds.), Language, migration and social inequalities: A critical sociolinguistic perspective on institutions and work (Vol. 2, pp. 56-78). Bristol: Multilingual Matters.

Anderson, B. (1991). Imagined communities: Reflections on the origins and spread of nationalism (revised ed.). New York: Verso.

Arnaut, K., Karrebæk, M. S., Spotti, M., \& Blommaert, J. (Eds.). (2016). Engaging superdiversity: recombining spaces, times and language practices. Bristol: Multilingual Matters.

Banda, F., Jimaima, H., \& Mokwena, L. (2019). Semiotic remediation of Chinese signage in the linguistic landscapes of two rural areas in Zambia. In A. Sherris \& E. Adami (Eds.), Making signs, translanguaging ethnographies: Exploring urban, rural and educational spaces (pp. 74-90). Bristol: Multilingual Matters.

Baraban, R. S., \& Durocher, J. F. (2010). Successful restaurant design. Oxford: Wiley.

Barker, J. R., \& Tompkins, P. K. (1994). Identification in the self-managing organization characteristics of target and tenure. Human Communication Research, 21(2), 223-240.

Barrett, R. (2006). Language ideology and racial inequality: Competing functions of Spanish in an Anglo-owned Mexican restaurant. Language in Society, 35(2), 163-204.

Bell, A. (2014). The guidebook to sociolinguistics. Chichester: Wiley Blackwell.

Biffl, G. (2016). Migration and labor integration in Austria. SOPEMI report on Labor Migration Austria 2015-2016. Report of the Austrian SOPEMI correspondent to the OECD. Monograph Series Migration and Globalisation, Krems (Edition Donau-Universität Krems).

Blackledge, A., \& Creese, A. (2017). Translanguaging and the body. International Journal of Multilingualism, 14(3), 250-268.

Blommaert, J., Collins, J., \& Slembrouck, S. (2005). Polycentricity and interactional regimes in 'global neighborhoods'. Ethnography, 6(2), 205-235.

Blommaert, J. (2010). The sociolinguistics of globalization. Cambridge: Cambridge University Press.

Blommaert, J. (2016). From mobility to complexity in sociolinguistic theory and method. In N. Coupland (Ed.), Sociolinguistics: Theoretical debates (pp. 242-259). Cambridge: Cambridge University Press.

Britain, D. (2012). Countering the urbanist agenda in variationist sociolinguistics: Dialect contact, demographic change and the rural-urban dichotomy. Dialectological and Folk Dialectological Concepts of Space, 17, 12-30.

Bourdain, A. (2007). Kitchen confidential. London: A\&C Black.

Burchell, G., Gordon, C., \& Miller, P. (Eds.). (1991). The Foucault effect. Studies in governmentality. Chicago: University of Chicago Press.

Canagarajah, A. S. (Ed.). (2013). Literacy as translingual practice: Between communities and classrooms. New York: Routledge.

Clyne, M. (1984). The German language in a changing Europe. Cambridge: Cambridge University Press.

Costen, W. M., \& Salazar, J. (2011). The impact of training and development on employee job satisfaction, loyalty, and intent to stay in the lodging industry. Journal of Human Resources in Hospitality \& Tourism, 10(3), 273-284.

Dannerer, M., \& Franz, M. (2018). Language and tourism in Austria with a focus on Tyrol. Sociolinguistica, 32(1), 169-184.

Dardot, P., \& Laval, C. (2014). The new way of the world: On neoliberal society. London: Sage.

Darvin, R., \& Norton, B. (2015). Identity and a model of investment in applied linguistics. Annual Review of Applied Linguistics, 35, 36-56.

Darvin, R., \& Norton, B. (2016). Investment and language learning in the 21st Century. Langage et société, 157(3), 19-38. https://doi.org/10.3917/1s.157.0019.

Davidson, M. C. (2003). Does organizational climate add to service quality in hotels? International Journal of contemporary hospitality management, 15(4), 206-213.

De Costa, P., Park, J., \& Wee, L. (2016). Language learning as linguistic entrepreneurship: Implications for language education. The Asia-Pacific Education Researcher, 25, 695-702. 
De Costa, P. I., Park, J., \& Wee, L. (2018). Linguistic entrepreneurship as affective regime: organizations, audit culture, and second/foreign language education policy. Language Policy, 18, 387-406.

Duchêne, A. (2011). Neoliberalism, social inequalities, and multilingualism: The exploitation of linguistic resources and speakers. Langage et société, 2, 81-108.

Duchêne, A., \& Heller, M. (Eds.). (2012). Language in late capitalism: Pride and profit. New York: Routledge.

Duchêne, A., Moyer, M., \& Roberts, C. (Eds.). (2013). Language, migration and social inequalities: A critical sociolinguistic perspective on institutions and work (Vol. 2). Bristol: Multilingual Matters.

Ferguson, C. A. (1959). Diglossia. Word, 15(2), 325-340.

Gal, S. (2006). Migration, minorities and multilingualism: Language ideologies in Europe. In C. MarMolinero \& P. Stevenson (Eds.), Language ideologies, policies and practices: Language and globalization (pp. 13-27). London: Palgrave Macmillan.

García, O., Flores, N., \& Spotti, M. (Eds.). (2017). The Oxford handbook of language and society. Oxford: Oxford University Press.

Geertz, C. (1973). The interpretation of cultures: Selected essays. New York: Basic Books.

Gershon, I. (2017). Down and out in the new economy. Chicago: Chicago University Press.

Gershon, I. (2011). Neoliberal agency. Current Anthropology, 52(4), 537-555.

Gibson, M. K., \& Papa, M. J. (2000). The mud, the blood, and the beer guys: Organizational osmosis in blue-collar work groups. Journal of Applied Communication Research, 28(1), 68-88.

Giddens, A. (1991). Modernity and self-identity: Self and society in the late modern age. Redwood City: Stanford University Press.

Goffman, E. (1959). The presentation of self in everyday life. London: Penguin Books.

Gonçalves, K., \& Schluter, A. (2017). "Please do not leave any notes for the cleaning lady, as many do not speak English fluently": Policy, power, and language brokering in a multilingual workplace. Language Policy, 16(3), 241-265.

Gonçalves, K. (2020). Language, inequality and global care work. International Journal of the Sociology of Language, 262, 1-15.

Goodall, H. L., Jr., \& Eisenberg, E. M. (1997). The dispossessed. In B. D. Sypher (Ed.), Case studies in organizational communication 2: Perspectives on contemporary work life (pp. 371-380). New York: Guilford Press.

Gumperz, J. (1965). Language. Biennial Review of Anthropology, 4, 84-120.

Harris, R. (1998). Introduction to integrational linguistics. Pergamon.

Hess, D. B. (in press). "The Filipinos, they can do it" - Migrant workers in a multilingual water manufacturing company in Saipan. In K. Gonçalves \& H. Kelly-Holmes (Eds.), Language, global mobilities, blue-collar workers and blue-collar workplaces. New York: Routledge.

Holborow, M. (2015). Language and neoliberalism. London: Routledge.

Holmes, J. (2011). Discourse and the workplace. In K. Hyland \& B. Paltridge (Eds.) Bloomsbury companion to discourse analysis (pp. 185-198).

Holmes, J., \& Marra, M. (2002). Having a laugh at work: How humour contributes to workplace culture. Journal of Pragmatics, 34(12), 1683-1710.

Holmes, J., \& Stubbe, M. (2015). Power and politeness in the workplace: A sociolinguistic analysis of talk at work. New York: Routledge.

Hornberger, N. H. (2015). Selecting appropriate research methods in LPP research: Methodological rich points. In F. M. Hult \& D. C. Johnson (Eds.), Research methods in language policy and planning: A practical guide (pp. 9-20). Oxford: John Wiley \& Sons.

Hua, Z., Otsuji, E., \& Pennycook, A. (2017). Multilingual, multisensory and multimodal repertoires in corner shops, streets and markets: introduction. Social Semiotics, 27(4), 383-393.

Jernudd, B. H. \& J.V. Neustupný. (1987). Language planning: for whom. In Proceedings of the international colloquium on language planning (pp. 69-84). Québec: Les Presses de L'Université Laval.

Johnstone, B. (2002). Discourse analysis. Malden: Blackwell Publishers.

Karatepe, O., \& Olugbade, O. (2009). The effects of job and personal resources on hotel employees' work engagement. International Journal of Hospitality Management, 28, 504-512.

King, L., \& Carson, L. (Eds.). (2016). The multilingual city: Vitality, conflict and change. Bristol: Multilingual Matters.

Kolleritsch, E. (2004). Input-output-multiplikatoren 2000. Statistische Nachrichten, 6, 593-601.

Kusters, A., Spotti, M., Swanwick, R., \& Tapio, E. (2017). Beyond languages, beyond modalities: Transforming the study of semiotic repertoires. International Journal of Multilingualism, 14(3), 219-232. 
Li, H., Qiang, Y., \& Law, R. (2013). Determinants of customer satisfaction in the hotel industry: An application of online review analysis. Asia Pacific Journal of Tourism Research, 18(7), 784-802.

Lorente, B. P. (2012). The making of "workers of the world": Language and the labor brokerage state. In A. Duchêne \& M. Heller (Eds.), Language in late capitalism (pp. 193-216). New York: Routledge.

Lorente, B. P. (2018). Scripts of servitude: Language, labor migration and domestic work. Bristol: Multilingual Matters.

Lynch, O. H. (2009). Kitchen antics: The importance of humor and maintaining professionalism at work. Journal of Applied Communication Research, 37(4), 444-464.

Martín Rojo, L., \& Del Percio, A. (Eds.). (2020). Language and neoliberal governmentality. New York: Routledge.

McAll, C. (2003). Language dynamics in the bi- and multilingual workplace. In R. Bayley \& S. Schecter (Eds.), Language socialization in bilingual and multilingual societies (pp. 235-250). Bristol: Multilingual Matters.

McElhinny, B. (2015). Language and political economy. In N. Bonvillain (Ed.), The Routledge handbook of linguistic anthropology (pp. 279-300). London and New York: Routledge.

Morreall, J. (1991). Humor and work. HUMOR: International Journal of Humor Research, 4(3-4), $359-374$.

Norton, B. (2000). Identity, acculturation, and language loss. In S. McKay \& S. L. Wong (Eds.), English language learners in the United States: A resource for teachers (pp. 443-461). Cambridge: Cambridge University Press.

Neustupný, J. V., \& Nekvapil, J. (2003). Language management in the Czech Republic. Current Issues in Language Planning, 4(3/4), 181-366.

Norris, S. (2004). Analyzing multimodal interaction. A methodological framework. London: Routledge.

OECD (2014). Austria: Country note-Education at a Glance 2014. Retrieved from: https://www.oecd. org/education/Austria-EAG2014-Country-Note.pdf.

Otsuji, E., \& Pennycook, A. (2010). Metrolingualism: Fixity, fluidity and language in flux. International Journal of Multilingualism, 7, 240-254.

Pang, P. (2018). Directives in professional kitchens and potential learning opportunities. Applied Linguistics, 40, 754-772.

Pavlenko, A. (2019). Superdiversity and why it isn't: Reflections on terminological innovation and academic branding. In B. Schmenk, S. Breidbach, \& L. Küster (Eds.), Sloganization in language education discourse: Conceptual thinking in the age of academic marketization (pp. 142-168). Bristol: Multilingual Matters.

Pennycook, A. (in press). Blue-collar work and multilingualism: 'C'est tough'. In K. Gonçalves \& H. Kelly-Holmes (Eds.), Language, global mobilities, blue-collar workers and workplaces. New York: Routledge.

Pennycook, A. (2017). Language policy and local practices. In O. García, N. Flores, \& M. Spotti (Eds.), The Oxford handbook of language and society (pp. 125-140). Oxford: Oxford University Press.

Pennycook, A., \& Otsuji, E. (2015). Metrolingualism: Language in the city. New York: Routledge.

Pennycook, A., \& Otsuji, E. (2016). Lingoing, language labels and metrolingual practices. Applied Linguistics Review, 7(3), 259-277.

Pietikäinen, S., Jaffe, A., Kelly-Holmes, H., \& Coupland, N. (2016). Sociolinguistics from the periphery: Small languages in new circumstances. Cambridge: Cambridge University Press.

Pietikäinen, S., \& Allan, K. (in press). "Jobs for life"?: Mining temporalities in a transforming arctic periphery. In K. Gonçalves \& H. Kelly-Holmes (Eds.), Language, global mobilities, blue-collar workers and blue-collar workplaces. London: Routledge.

Roberts, C. (2010). Language socialization in the workplace. Annual Review of Applied Linguistics, 30, 211-227.

Russ, C. (Ed.). (1990). The dialects of modern German: A linguistic survey. New York: Routledge.

Rymes, B. (2014). Communicative Repertoire. In C. Leung \& B. V. Street (Eds.), The Routledge handbook of english language studies. New York: Routledge.

Schluter, A. (2018). When socio-political pressure is more powerful than the boss: Workplace language policies by Kurds that restrict Kurdish. Language Policy. https://doi.org/10.1007/s1099 3-018-9505-3.

Silverstein, M. (1992). The indeterminancy of contextualization: When enough is enough? In P. Auer \& A. Di Luzio (Eds.), The contextualization of language (pp. 55-75). Amsterdam: John Benjamins.

Sherris, A., \& Adami, E. (Eds.). (2019). Making signs, translanguaging ethnographies: Exploring urban, rural and educational spaces. Bristol: Multilingual Matters. 
Smith, L. C., \& Baker, W. (2011). L2 dialect acquisition of German vowels: The case of Northern German and Austrian dialects. Poznan Studies in Contemporary Linguistics, 47(1), 120.

Sohn, E. M., \& Lee, K. W. (2018). The effect of chefs' nonverbal communication in open kitchens on service quality. Journal of Foodservice Business Research, 21(5), 483-492.

Spolsky, B. (2018). A modified and enriched theory of language policy (and management). Language Policy, 18, 323-338.

Spotti, M., Kroon, S., \& Li, J. (2019). New speakers of new and old languages: An investigation into the gap between language practices and language policy. Language Policy, 18, 535-551.

Statistics Austria. (2017). http://www.statistik.at/web_de/services/publikationen/13/index.html?inclu dePage $=$ detailedView $\$$ ionName $=$ Tourismus\&pubId=532. Accessed Feb 2019.

Strömmer, M. (in press). Physical work, customer service or teamwork? Language requirements for seasonal cleaning work in the booming Arctic tourism industry. In K. Gonçalves \& H. Kelly-Holmes (Eds.), Language, global mobilities, blue-collar workers and blue-collar workplaces. New York: Routledge.

Thurlow, C., \& Jaworski, A. (2010). Tourism discourse: Language and global mobility. London: Palgrave Macmillan.

Tse, L. (1996). Language brokering in linguistic minority communities: The case of Chinese-and Vietnamese-American students. Bilingual Research Journal, 20(3-4), 485-498.

Urciuoli, B. (2008). Skills and selves in the new workplace. American Ethnologist, 35(2), 211-228.

Vertovec, S. (2007). Super-diversity and its implications. Ethnic and Racial Studies, 30(6), 1024-1054.

Wei, L. (2011). Moment analysis and translanguaging space: Discursive construction of identities by multilingual Chinese youth in Britain. Journal of Pragmatics, 43(5), 1222-1235.

WKO (2017). Statistical yearbook 2017. Retrieved Feb. 2019, from: https://wko.at/statistik/jahrb uch/2017_Englisch.pdf.

Wiesinger, P. (1990). The Central and Southern Bavarian dialects in Bavaria and Austria. In C. Russ (Ed.), The dialects of modern German: A linguistic survey (pp. 438-519). New York: Routledge.

Wodak, R., \& Boukala, S. (2015). (Supra) National identity and language: Rethinking national and European migration policies and the linguistic integration of migrants. Annual Review of Applied Linguistics, 35, 253-273. https://doi.org/10.1017/S0267190514000294.

Publisher's Note Springer Nature remains neutral with regard to jurisdictional claims in published maps and institutional affiliations. 